\title{
Identifikasi Tumbuhan Paku Sejati (Filicopytha) di Kawasan Hutan Wisata Aik Nyet sebagai Sumber Belajar Biologi
}

\author{
Novi Heryani Putri ${ }^{1}$, Ahmad Raksun ${ }^{2 *}$, I Gde Mertha ${ }^{2}$ \\ ${ }^{1,2}$ Program Studi Pendidikan Biologi PMIPA FKIP Universitas Mataram \\ *Email: ahmadraksun@gmail.com,
}

Diterima: 24 April 2018 Publish: 28 Juni 2018

\begin{abstract}
Abstrak
KawasanWisata Aik Nyet merupakan kawasan hutan hujan tropis yang memiliki ketinggian 350 hingga 550 mdpl. Di kawasan hutan wisata ini banyak memiliki kekayaan, keanekaragaman hayati yang mempunyai nilai penting bagi kehidupan dan kesejahteraan manusia, di antaranya adalah tumbuhan paku sejati yang masih belum banyak mendapat perhatihan oleh masyarakat. Tujuan penelitian ini adalah untuk mengidentifikasi jenis-jenis tumbuhan paku sejati (Filocopyta) di Kawasan Hutan Wisata Aik Nyet. Prosedur pengumpulan sampel menggunakan metode jelajah. Identifikasi sampel menggunakan beberapa buku, dan situs web. Data yang dikumpulkan diidentifikasi dan dideskripsikan berdasarkan sifat dan cirinya. Hasil penelitian diperoleh 36 spesies. Spesies yang telah diidentifikasi tersebut terklasifikasi dalam 2 ordo, 9 famili, 26 genus. Jenis tumbuhan paku yang paling banyak ditemukan berasal dari Ordo Polipodiales yaitu Famili Polypodiaceae 11 spesies.
\end{abstract}

Kata kunci: identifikasi tumbuhan paku, hutan Wisata Aik Nyet

\begin{abstract}
Aik Nyet Tourism Forest is a tropical rain forest area that has an altitude of 350 to 550 MDPL. In this forest area abundant biological resources, biodiversity that has important value for life and human welfare, among them is a fern, which still have not received much attention from the people. The objectives of this study were to identify the species of fern(Filocopyta). The sample collection procedure uses the roaming method. Identify samples using multiple books, and websites. The data collected is identified and described by its characteristics. The results obtained 36 species. Species that have been identified are classified into 2 orders, 9 families, 26 genera. The most common type of fern from the Polipodiales Order is the 11 species Polypodiaceae Family.
\end{abstract}

Keywords: Identification Fern, Aik Nyet Tourism Forest 


\section{Pendahuluan}

Negara Indonesia merupakan Negara yang sebagian wilayahnya berupa hutan. Hutan adalah kesatuan ekosistem berupa hamparan lahan yang berisi sumberdaya alam hayati yang didominasi pepohonan dalam persekutuan alam lingkungannya, yang satu dan yang lainnya tidak dapat dipisahkan.Hutan secara umum dikenal sebagai suatu sumberdaya yang sangat unik, yang member manfaat sangat beragam bagi kehidupan baik secara langsung ataupun tidak langsung. Tumbuhan epifit merupakan bagian signifikan dari seluruh jenis tumbuhan yang dapat dijumpai di hutan tropis. Epifit merupakan salah satu kelompok tumbuhan penyusun komunitas hutan, jenisnya sangat beranekaragam mulai dari algae, lumut, jamur, paku-pakuan, anggrek hingga tumbuhan berkayu.

Tumbuhan paku merupakan kelompok tumbuhan yang termasuk dalam divisi Pteriodophyta. Tumbuhan paku menyenangi daerah yang lembab. Tumbuhan paku dikelompokkan dalam satu divisi yang jenis-jenisnya telah jelas mempunyai kormus dan dapat dibedakan dalam tiga bagian pokok yaitu akar, batang, dan daun.

Cara untuk mengenal tumbuhan paku yaitu umumnya dicirikan oleh pertumbuhan pucuknya yang melingkar. Disamping itu pada permukaan bawah daunnya ada bintik-bintik yang kadangkadang tumbuh teratur dalam barisannya, menggerombol dan tersebar. Bintik-bintik itu adalah kotak spora yang dikenal dengan istilah sporangium. Dengan spora ini tumbuhan paku dapat memperbanyak diri. Secara tidak langsung, kehadiran tumbuhan paku turut memberikan manfaat dalam memelihara ekosistem hutan antara lain, membantu menjaga lahan pegunungan terhadap bahaya erosi serta mengatur tata guna air dalam tanah sehingga membuat tanah tetap lembab (Sujalu, 2014).

Menurut Polunin (1994) bahwa tumbuhan paku yang sering digunakan sebagai tanaman hias adalah family Licopodiinae karena tumbuhan suka panas, serta tumbuhan paku yang sering digunakan dalam pembuatan karangan bunga adalah paku kawat (Lycopodium sp.). Helminthostachyszeylanica merupakan salah satu tumbuhan paku yang telah lama digunakan oleh masyarakat sebagai obat tradisional (Fitryadan Anwar, 2009).

Hutan Wisata Aik Nyet terletak di

Desa Buwun Sejati, Kecamatan Narmada, Kabupaten Lombok Barat, setelah mengalami pemekaran dari Desa Sesaot pada tahun 2011. Luas wilayah Desa Buwun Sejati 1.414.18 Ha. Luas Hutan Desa Buwun Sejati memiliki luas kira-kira 1.250 ha dan memiliki ketinggian 350-550 m dpl dengan kemiringan tanah $8 \%$. Adanya berbagai jenis tanaman yang tumbuh di Hutan Wisata Aik Nyet tersebut menjadikan keberadaan ekosistem hutan tersusun dengan baik, karena peranan dari tumbuhan itu adalah sebagai pemasok oksigen ke lingkungan dan sebagai 
sumber makanan bagi organism heterotof.

Dalam proses pembelajaran biologi peserta didik mengalami kesulitan dalam menyebutkan atau mengingat nama latin. Oleh karena itu proses pembelajaran biologi tidak hanya sekedar interaksi komunikasi dan materi dari pendidik kepada peserta didik, tetapi harus dapat menciptakan interaksi langsung antara peserta didik dengan obyek belajar yang dipelajari yaitu lingkungan. Lingkungan dapat dimanfaatkan sebagai sumber belajar biologi yang dapat menunjang siswa lebih mengenal lingkungan dengan melakukan pengamatan dan kegiatan ilmiah. Melalui kegiatan ilmiah siswa dapat pengalaman baru yang tidak dijumpai dengan hanya membaca buku.

Berdasarkan uraian di atas, maka perlu adanya penelitian identifikasi tumbuhan paku di Kawasan Hutan Wisata Aik Nyet yang dapat digunakan sebagai sumber belajar biologi di sekolah dan untuk memberikan informasi kepada masyarakat mengenai jenis-jenis tumbuhan paku sejati terutama yang bermanfaat bagi kehidupan. Sehubungan dengan kepentingan tersebut maka dilakukan penelitian yang berjudul Identifikasi Tumbuhan Paku (Filicopyta) di Kawasan Hutan Wisata Aik Nyet Sebagai Sumber Belajar Biologi. Tujuan dilaksanakannya penelitian ini adalah untuk mengidentifikasi jenis-jenis tumbuhan paku sejati (Filocophyta) di Kawasan Hutan Wisata Aik Nyet.

\section{Bahan dan Metode}

Bahan-bahan yang digunakan dalam penelitian ini yaitu Alkohol 95\%, Aquades, kertas koran,dan plastik beras. Sedangkan alat-alat yang digunakan yaitu Global Positioning System (GPS), loope kecil, kamera, label gantung, alat tulis, spidol permanen, selotip, Hygromrter, $\mathrm{pH}$ meter tanah, termometer, meteran, dan buku identifikasi.

Penelitian ini dilakukan pada bulan September 2017 di Kawasan Hutan Wisata Aik Nyet. Pengambilan data dilakuan dengan metode ekspolarasi atau jelajah, artinya peneliti menjelajahi setiap sudut suatu lokasi. Apabila waktu yang tersedia masih cukup memadai sedangkan seluruh lokasi telah terjelajahi, maka sebaiknya dilakukan penyusuran kembali di lokasi yang sama dengan tujuan mengetahui apakah tumbuhan yang di lokasi tersebut telah terkumpul semua (Rugayah, 2004). Sampel yang berhasil dikumpulkan selanjtunya diidentifikasi dengancaramencocokkancirimorfologisa mpeldenganbukuacuan Sri Mulyani,AnatomiTumbuhanRendah, Holtum, R Flora of Malaysia. Volume 2 Ferus of Malaya. 2.nd Government Printing Office.Singapore, Tjitrosoepomo G KlasifikasiTumbuhanPaku.

Data hasil penelitian dianalisis secara kualitatif. Hasil penelitian ini dianalisa secara deskriptif dan ditampilkan dalam bentuk tabel dan foto. Hasil inventarisasi akan menjadi 
sumber bahan ajar biologi melalui identifikasi

\section{Hasil dan Pembahasan}

Berdasarkan penelitian yang telah dilakukan, terdapat 36 spesies yang dikoleksi pada lokasi penelitian yang terdiri dari 9 famili dan 2 ordo. Spesies yang ditemukan di lokasi penelitian didominasi oleh spesies dari ordo Polipodiales yakni sebanyak 34 spesies, sedangkan spesies lainnya dari ordo Cyatheales. Ordo Polipodiales lebih banyak ditemukan pada lokasi penelitian sebab kondisi lingkungan pada lokasi penelitian sangat sesuai bagi kelangsungan hidup spesies tersebut.

Tabel 1. Spesies-Spesies Tumbuhan Paku Sejati yang ditemukan pada Kawasan Hutan Wisata Aik Nyet

\begin{tabular}{|c|c|c|c|c|}
\hline No. & Ordo & Famili & Genus & Nama Spesies \\
\hline \multirow{2}{*}{1.} & \multirow{2}{*}{ Cyatheales } & \multirow{2}{*}{ Cyatheaceae } & Cyathea & C.latebrosa \\
\hline & & & Cyathea & C.obscura \\
\hline \multirow{26}{*}{2.} & \multirow{26}{*}{ Polipodiales } & \multirow{11}{*}{ Polypodiaceae } & Pyrrosia & P.longifolia \\
\hline & & & Pyrrosia & P.numularifolia \\
\hline & & & Microsorum & M.punctatum \\
\hline & & & Goniophlebium & G.subauriculatum \\
\hline & & & Goniophlebium & G.verrucosum \\
\hline & & & Belvisia & B.callifolia \\
\hline & & & Phymatosorus & P.scolopendria \\
\hline & & & Dynaria & D.quercifolia \\
\hline & & & Microsorum & M.pteropus \\
\hline & & & Davallia & D. denticulate \\
\hline & & & Pityrogramma & P.calomelanos \\
\hline & & \multirow{6}{*}{ Thelypteridaceae } & Sphaerostepahnos & S.polycarpus \\
\hline & & & Penumatopteris & P.truncata \\
\hline & & & Cyclosorus & C. interruptus \\
\hline & & & Christella & C.dentata \\
\hline & & & Christella & C.arida \\
\hline & & & Amphineuron & A.immersum \\
\hline & & \multirow{8}{*}{ Pteridaceae } & Pteris & P.vittata \\
\hline & & & Pteris & P.biaurita \\
\hline & & & Pteris & P.mertensioides \\
\hline & & & Pteris & P.ensiformis \\
\hline & & & Pteris & P.australis \\
\hline & & & Adiantum & A.stenoclamys \\
\hline & & & Vittaria & V.ensiformis \\
\hline & & & Antrophyum & A.callifolium \\
\hline & & Dennstaedtiaceae & Microlepia & M.trapeziformis \\
\hline
\end{tabular}




\begin{tabular}{|l|l|l|l|}
\hline \multirow{3}{*}{} & & Hypolepis & H.beddomei \\
\cline { 3 - 4 } & Aspleniaceae & Asplenium & A.nidus \\
\cline { 3 - 4 } & \multirow{2}{*}{ Athyriaceae } & Diplazium & D.esculentum \\
\cline { 3 - 4 } & & Diplazium & D. asperum \\
\cline { 3 - 4 } & Tectariaceae & Tectaria & T.griffithii \\
\cline { 3 - 4 } & \multirow{3}{*}{ Dryopteridaceae } & Bolbitis & B.virens \\
\cline { 3 - 4 } & & Nephrolepis & N.biserrata \\
\cline { 3 - 4 } & & Nephrolepis & N. falcate \\
\hline
\end{tabular}

Data hasil penelitian tersebut menunjukkan bahwa menujukan bahwa family Polypodiaceae memiliki komposisi genus dan family tertinggi dibandingkan dengan famililainya. Famili dengan komposisi genus dan spesies paling sedikit dari family Aspleniaceae.

\section{Pengukuran Faktor Fisik Lingkungan}

Pengukuran parameter fisikakimia dilakukan untuk mengetahui apakah kondisi fisik lingkungan masih sesuai dengan kondisi fisik yang ideal. Hasil pengukuran parameter fisikakimia pada lokasi penelitian menunjukkan hasil masih layak bagi kelangsungan hidup tumbuhan pakus ejati. Pengukuran suhu menunjukkan hasil sebesar $26^{0} \mathrm{C}$, kelembapan udara sebesar 89,5\%, dan $\mathrm{pH}$ tanah sebesar 6,7 .

\section{Penutup}

Berdasarkan hasil penelitian dapat disimpulkan bahwa tumbuhan paku sejati yang teridentifikasi ada 2 ordo yakni Polipodiales dan Cyatheales. Terdiridari 9 famili, 26 genus dan 36 spesies. Penelitian ini dapat dijadikan sumber belajar biologi berupa booklet.
Daftar Pustaka

Fitrya dan Anwar, L.2009. Uji Aktivitas Anti kanker Secara In Vitro dengan Sel Murine P-388 Senyawa Flavonoid dari Fraksi Etilasetat Akar Tumbuhan Tunjuk Langit (Helmyn thostachis Zeylanica (Linn) Hook). Jurnal Penelitian Sains. 12(1): 1-4.

Polunin, N.1994. Pengantar Geografi Tumbuhan, Yogyakarta : Gadjah Mada University Press.

Rugayah,ElizabethA. Widjaja, Praptiwi. 2004, Pedoman Pengumpulan Data Keanekaragaman Flora, Bogor : LIPI.

SriMulyani.E.S. 2006. Anatomi Tumbuhan Rendah, Yogyakarta :Penerbit Kanisius.

Sujalu,A.P. $2007 . \quad$ Identifikasi Keanekaragaman Paku-Pakuan (Pteridophyta) Epifit Pada Hutan Bekas Tebangan Di Hutan Penelitian Malinau-Cifor Seturan. Media Konservasi 12(1):38-48.

Van C.G.G.J., dan Steenis.2013. Flora, untuk sekolah di Indonesia. Jakarta: PT Balai Pustaka (Persero). 